\title{
Dissolution Profiles of Three Brands of Lamivudine and Zidovudine Combinations in the Nigerian Market
}

\author{
N. A. Ochekpe ${ }^{1,2}$, N.C. Ngwuluka ${ }^{1}$, \\ H. Owolayo ${ }^{1}$, T. Fashedemi ${ }^{1}$
}

Introduction

G lobally, it is estimated that about $90 \%$ of people infected with HIV/AIDS live in the developing countries, while $70 \%$ of the world's total of HIV-positive people live in Sub-Saharan Africa. It is also estimated that about 15 million Africans may have died from AIDS since the beginning of the epidemic, with southern and eastern Africa being the most severely affected regions (1). The first diagnosis of HIV/AIDS in Nigeria was made in 1986. From the sentinel survey, November 1999, 5.4\% of the adult population (about 2.6 million) was living with HIV. By 2001, the population living with HIV rose to $5.8 \%$ (2). Approximately $85 \%$ of AIDS patients were aged 20 to 49 years.

Progress has been made in the management and treatment of HIV/AIDS with antiretroviral medicines. Although AIDS still cannot be cured, the quality and length of life for HIV-infected people have been improved using antiretroviral therapy. Drugs for HIV and opportunistic infections are administered concurrently for the lifetime of an infected person. The first line of antiretroviral drugs (ARVs) includes lamivudine, stavudine, and nevirapine (2). The first drug to be approved for the treatment and management of patients with AIDS was zidovudine in 1987 (1).

Emerging incidences of resistant HIV strains have led to the combination of ARVs. It is known that a combination of zidovudine and lamivudine reduced disease progression by $66 \%$. The combination reduced viral RNA and increased $\mathrm{CD}^{+}$cell counts for a period extending beyond 76 weeks in a group of HIV-positive patients.

A major challenge to treatment scale-up is the low availability of and delays in the delivery of ARVs. Presently, the Nigerian government is the main provider of antiretroviral services in the country (3) and there is a determined effort to further reduce the cost of ARVs to make it affordable to patients. With the local manufacture of generic ARVs, the need to monitor the quality of these drugs cannot be over emphasized. In a 2003 study by Abuga et al. (4), of the 33 samples studied, 3 failed to meet the percent content required.

The release of active pharmaceutical ingredient from drug product, the dissolution of the drug under physiological conditions, and the permeability across the gastrointestinal tract determine the drug absorption. Based on this, in vitro dissolution may be vital in assessing in vivo perfor- mance. Dissolution testing serves as a tool to distinguish between acceptable and unacceptable products. It is also used to assess the lot-to-lot quality of a drug product and can guide the development of new formulations (5).

Three formulations of the combination of lamivudine and zidovudine found in the Nigerian market at the time of this study were used. Virex-LZ is a registered trade name of Fidson Healthcare, a Nigerian pharmaceutical company, and is the first ARV to be produced locally. Lazid is a registered name by Emcure of India and marketed by FIL Pharmaceuticals, Lagos, Nigeria. Combivir is manufactured by GlaxoSmithKline of India and marketed by GlaxoSmithKline, Nigeria. Combivir is on the WHO list of pre-qualified ARVs.

The goal of this work was to characterize the dissolution profile of Virex-LZ and compare it with those of the other two non-locally formulated $A R V s$, one of which is pre-qualified by the WHO. Three dissolution media were employed with the aim of meeting the FDA requirements for obtaining a waiver of in vivo bioavailability and bioequivalence studies.

\section{Materials and Methods}

Three solid dosage formulations of lamivudine and zidovudine combination were studied:Combivir (Batch No. B131358), Lazid (Batch No. LLZ0401), and Virex-LZ (Batch No. TA4100T). They were obtained directly from the manufacturers through direct representatives. The six tablets of each brand were individually weighed before use in the dissolution studies. Lamivudine (ILAC 1040116) and zidovudine (GZIC1140021) standards were obtained from Saimirra Innopharm PVT Ltd, Chennai, India.

Methanol HPLC/SPECTRO grade was obtained from Tedia, Inc., Fairfield, Ohio, USA; sodium acetate (anhydrous) was purchased from Belami fine chemicals, PVT, India; glacial acetic acid and hydrochloric acid ( $33 \% \mathrm{v} / \mathrm{v})$ were of analytical grade and used as received. All other solvents and reagents were of analytical grade or equivalent.

\section{Dissolution Media}

The three dissolution media employed were $0.1 \mathrm{~N}$ hydrochloric acid and phosphate buffers at $\mathrm{pH} 4.5$ and 6.8. The preparations of phosphate buffer $\mathrm{pH} 6.8$ and $0.1 \mathrm{~N}$ hydrochloric acid were from USP XXIII, 1995. Phosphate buffer $\mathrm{pH} 4.5$ was prepared by adjusting $20 \mathrm{mM}$ disodium

\footnotetext{
${ }^{1}$ Faculty of Pharmaceutical Sciences, University of Jos, PMB 2048, Jos, Nigeria.
} 
hydrogen phosphate to $\mathrm{pH} 4.5$ with ortho-phosphoric acid. These media were selected based on the FDA Guidance for Industry and the need to meet the criteria for biowaiver (6).

\section{Dissolution test apparatus}

Dissolution was carried out using Veego Scientific digital tablet dissolution test apparatus II, model DA-6D, with six vessels of 1-L capacity made by Veego Scientific, India.

Dissolution of tablets was carried out in six vessels, each containing $900 \mathrm{~mL}$ of the dissolution media, at $50 \pm 1 \mathrm{rpm}$. The dissolution media were heated to $37 \pm 0.2^{\circ} \mathrm{C}$. Threemilliliter (3- $\mathrm{mL}$ ) samples were withdrawn at time intervals $10,20,30,40,50$, and 60 minutes, and $3 \mathrm{~mL}$ of the media was replaced after each withdrawal. The concentration and quantity of the active pharmaceutical ingredients of each sample were determined using liquid chromatography (LC).

\section{LC System}

The LC system used for analysis was a Cecil 4000 series (Cecil Instruments, Cambridge, UK) comprising CE4100 pump, a CE4201 UV detector set at $265 \mathrm{~nm}$, and a $20-\mu \mathrm{L}$ fixed loop sample injector. The separation was performed at room temperature on a Waters Spherisorb ${ }^{\circledR}$ ODSB C18 reversed phase column, $5-\mu \mathrm{m}$ particle size, $250 \mathrm{~mm} \mathrm{X} 4.6$ $\mathrm{mm}$ ID. Data acquisition was performed with the CE4901 PowerStream ${ }^{\circledR}$ system manager and software. The PowerStream ${ }^{\circledR}$ software was used to program the HPLC instrument and to process the data (area integration, calculation, and plotting of chromatograms) throughout the method validation and sample analysis.

\section{Mobile Phase}

Sodium acetate (anhydrous) buffer was prepared and mixed with methanol in the ratio of 70:30 and the $\mathrm{pH}$ was adjusted to 4.5 with glacial acetic acid.

\section{Samples for HPLC analysis}

Three-milliliter samples were withdrawn and filtered using Whatman filter paper 540 . Aliquots $(1.5-\mathrm{mL})$ of the filtered samples were diluted to $5 \mathrm{~mL}$ with methanol (HPLC grade). The 20- $\mu \mathrm{L}$ fixed loop was overfilled with sample for injection using a $100-\mu \mathrm{L}$ injection syringe.

\section{Preparation of Standards}

Zidovudine $(25 \mathrm{mg}$ ) and lamivudine $(30 \mathrm{mg})$ were weighed separately and diluted to $50 \mathrm{~mL}$ with the three media to obtain stock solutions. To obtain zidovudine and lamivudine solutions for calibration (maintaining the ratio of 2:1), serial dilutions were carried out using methanol as the solvent. The standard concentrations were in the range of $20-120 \mu \mathrm{g} / \mathrm{mL}$ for zidovudine and $9.6-57.8 \mu \mathrm{g} / \mathrm{mL}$ for lamivudine.

\section{Data Analysis}

The PowerStream ${ }^{\circledR}$ software was used to program the HPLC and to acquire and process the primary data. Excel (Microsoft Corp., USA) was used to calculate the percent dissolved of the active pharmaceutical ingredients (APIs) for six individual tablets, and the mean and standard deviation were obtained. The similarity factor, $\mathrm{f}_{2}$, was used to compare the dissolution profiles of the different products as required (5).

\section{RESULTS AND DISCUSSION}

The results obtained for the three formulations of lamivudine and zidovudine are shown in Tables 1 to 7 and Figures 1 to 6 . A chromatogram of the dissolution specimen in $0.1 \mathrm{~N}$ $\mathrm{HCl}$ at $60 \mathrm{~min}$ is shown in Figure 7. This chromatogram shows good resolution between zidovudine and lamivudine. The APIs in Lazid and Virex-LZ showed complete dissolution in the three media, although it appears that $0.1 \mathrm{~N} \mathrm{HCl}$ favored their dissolution slightly more than the other two media. The dissolution of Combivir appears to be best in $\mathrm{pH}$ 4.5 phosphate buffer in this study.

According to the FDA Guidance for Industry, Waiver of In Vivo Bioavailability and Bioequivalence Studies for Imme-

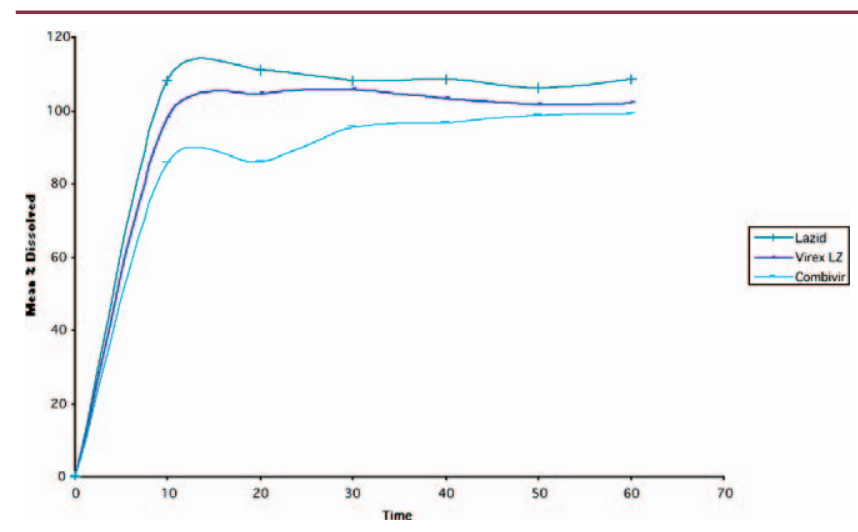

Figure 1. Comparative dissolution profiles of lamivudine in $0.1 \mathrm{~N} \mathrm{HCl}$.

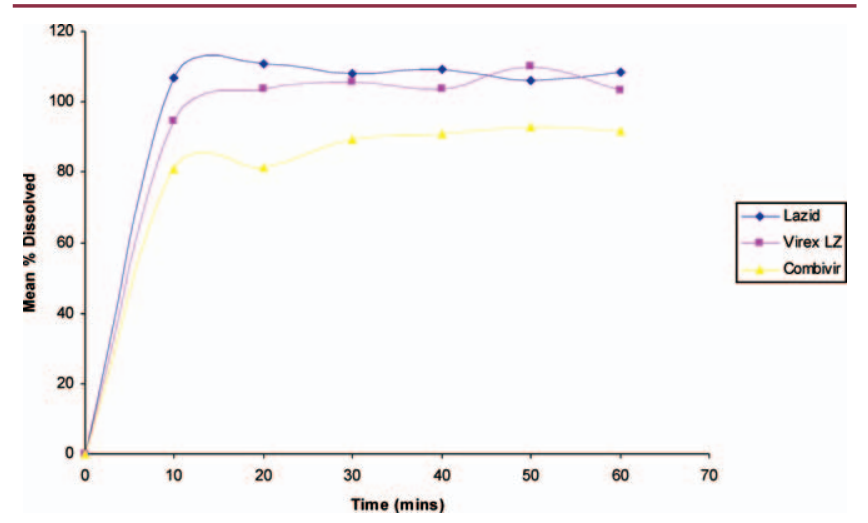

Figure 2. Comparative dissolution profiles of zidovudine in $0.1 \mathrm{~N} \mathrm{HCl}$. 
diate-Release Solid Oral Dosage Forms (6), a product is said to be rapidly dissolving when not less than $85 \%$ of the labeled API dissolves within 30 minutes. As evidenced from Tables 3 and 4, the products tested can be said to be rapidly dissolving in the three media, except for Combivir in $\mathrm{pH} 6.8$ phosphate buffer with respect to zidovudine release.

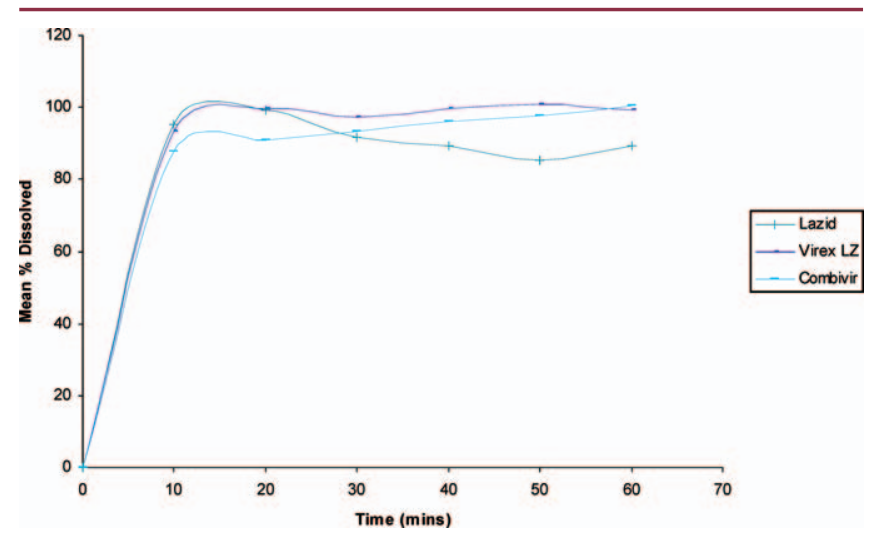

Figure 3. Comparative dissolution profiles of lamivudine in $\mathrm{pH} 4.5$ buffer.

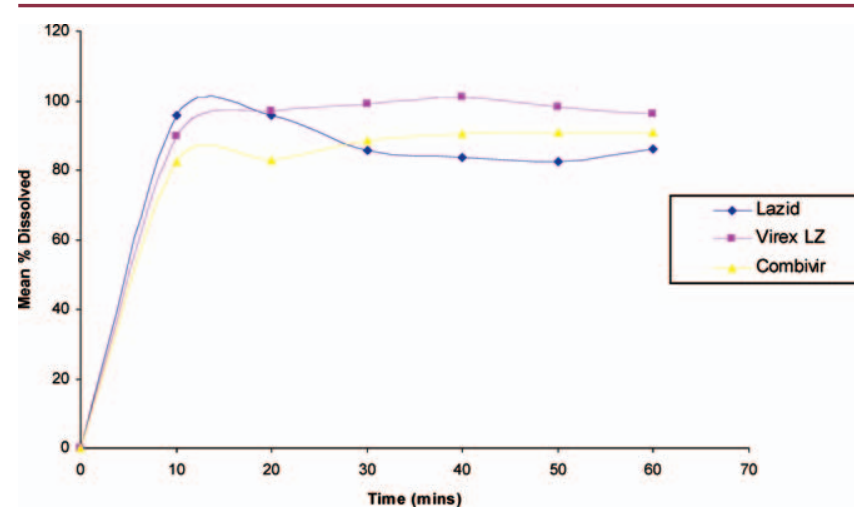

Figure 4. Comparative dissolution profiles of zidovudine in $\mathrm{pH} 4.5$ buffer.

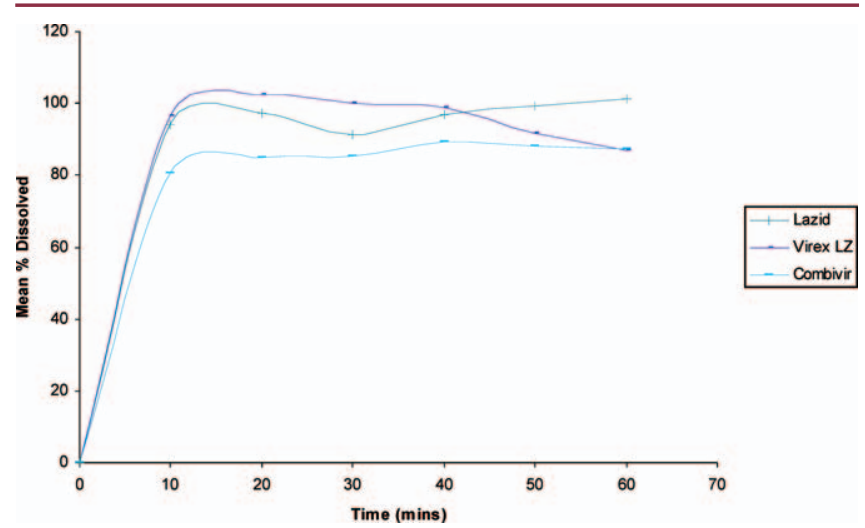

Figure 5. Comparative dissolution profiles of lamivudine in $\mathrm{pH} 6.8$ phosphate buffer.

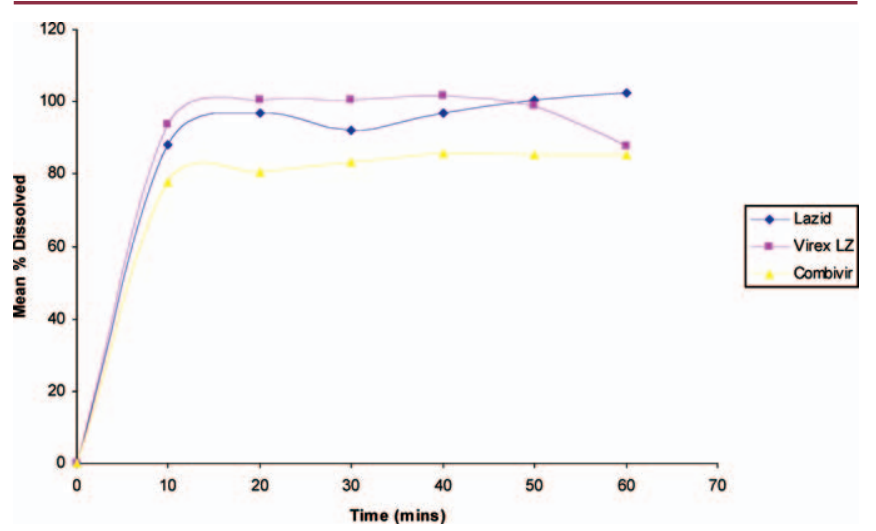

Figure 6. Comparative dissolution profiles of zidovudine in $\mathrm{pH} 6.8$ phosphate buffer.

The 1997 FDA Guidance for Industry on dissolution testing of immediate-release solid oral dosage forms (5) states that for highly-soluble and rapidly dissolving drug products (Biopharmaceutics Classification System, BCS classes 1 and 3), $85 \%$ dissolution in $0.1 \mathrm{~N} \mathrm{HCl}$ in 15 min can
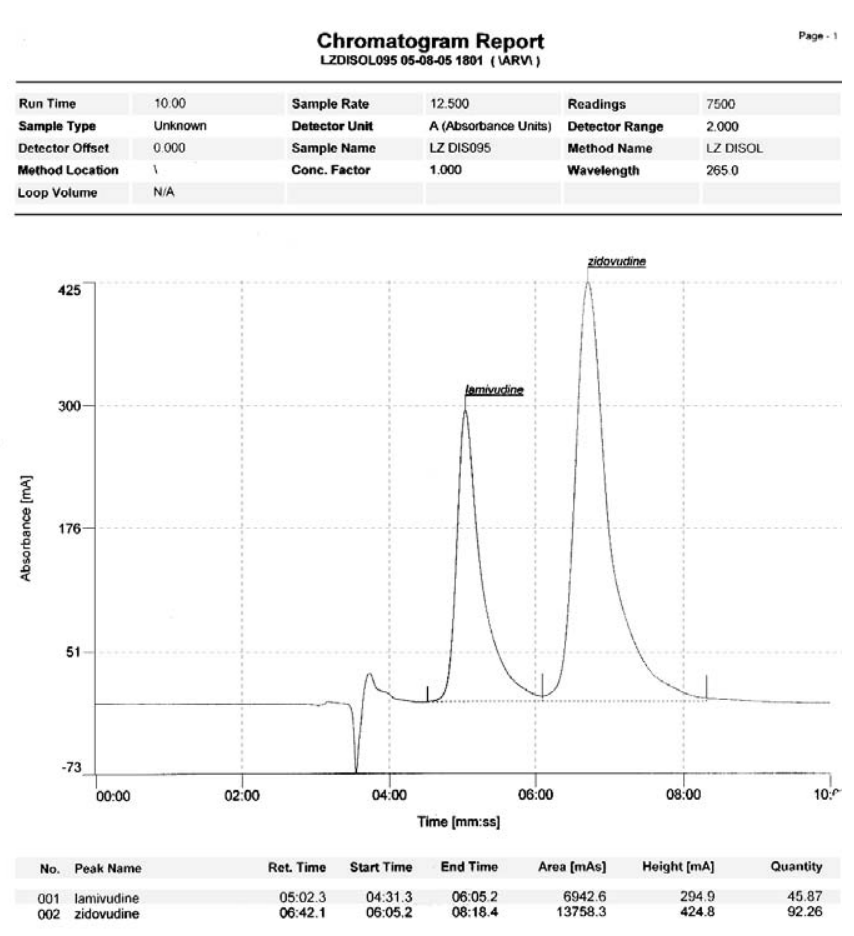

Figure 7. Typical chromatogram of the dissolution specimen in $0.1 \mathrm{~N} \mathrm{HCl} \mathrm{at}$ $60 \mathrm{~min}$. 


\begin{tabular}{|c|c|c|c|c|c|c|c|c|}
\hline \multicolumn{9}{|c|}{ Table 1} \\
\hline \multicolumn{5}{|c|}{ Lamivudine in Phosphate Buffer 4.5} & \multicolumn{4}{|c|}{ Zidovudine in Phosphate Buffer 4.5 } \\
\hline \multicolumn{3}{|c|}{ Reference (Combivir) } & \multicolumn{2}{|c|}{ Test (Virex-LZ) } & \multicolumn{2}{|c|}{ Reference (Combivir) } & \multicolumn{2}{|c|}{ Test (Virex-LZ) } \\
\hline Time(min) & $\begin{array}{c}\text { Mean \% } \\
\text { Dissolved }\end{array}$ & STDEV & $\begin{array}{c}\text { Mean \% } \\
\text { Dissolved }\end{array}$ & STDEV & $\begin{array}{c}\text { Mean \% } \\
\text { Dissolved }\end{array}$ & STDEV & $\begin{array}{c}\text { Mean \% } \\
\text { Dissolved }\end{array}$ & STDEV \\
\hline 10 & 87.7 & 3.92 & 93.1 & 3.75 & 82.3 & 3.08 & 89.8 & 3.90 \\
\hline 20 & 91.1 & 3.22 & 99.5 & 1.18 & 82.8 & 2.63 & 97.0 & 0.69 \\
\hline 30 & 93.5 & 2.49 & 97.2 & 9.72 & 88.7 & 4.67 & 98.9 & 4.60 \\
\hline 40 & 96.0 & 4.26 & 99.6 & 5.91 & 90.6 & 5.00 & 101.1 & 5.67 \\
\hline 50 & 97.5 & 4.98 & 100.7 & 1.92 & 90.8 & 2.87 & 98.3 & 2.65 \\
\hline 60 & 100.5 & 3.59 & 99.3 & 4.62 & 90.9 & 8.65 & 96.0 & 4.62 \\
\hline & & & & & $f 2=47.9$ & & & \\
\hline
\end{tabular}

\begin{tabular}{|c|c|c|c|c|c|c|c|c|}
\hline \multicolumn{5}{|c|}{ Lamivudine in Phosphate Buffer 4.5 } & \multicolumn{4}{|c|}{ Zidovudine in Phosphate Buffer 4.5 } \\
\hline \multicolumn{3}{|c|}{ Reference (Combivir) } & \multicolumn{2}{|c|}{ Test (Lazid) } & \multicolumn{2}{|c|}{ Reference (Combivir) } & \multicolumn{2}{|c|}{ Test (Lazid) } \\
\hline Time (min) & $\begin{array}{c}\text { Mean \% } \\
\text { Dissolved }\end{array}$ & STDEV & $\begin{array}{c}\text { Mean \% } \\
\text { Dissolved }\end{array}$ & STDEV & $\begin{array}{c}\text { Mean \% } \\
\text { Dissolved }\end{array}$ & STDEV & $\begin{array}{c}\text { Mean \% } \\
\text { Dissolved }\end{array}$ & STDEV \\
\hline 10 & 87.7 & 3.92 & 95.3 & 6.91 & 82.3 & 3.08 & 95.6 & 1.84 \\
\hline 20 & 91.1 & 3.22 & 99.2 & 3.16 & 82.8 & 2.63 & 95.8 & 4.33 \\
\hline 30 & 93.5 & 2.49 & 91.7 & 4.14 & 88.7 & 4.67 & 85.5 & 4.00 \\
\hline 40 & 96.0 & 4.26 & 89.2 & 4.47 & 90.6 & 5.00 & 83.5 & 2.52 \\
\hline 50 & 97.5 & 4.98 & 85.4 & 2.99 & 90.8 & 2.87 & 82.3 & 3.60 \\
\hline 60 & 100.5 & 3.59 & 89.1 & 5.01 & 90.9 & 8.65 & 86.2 & 5.67 \\
\hline & & & & & \multicolumn{4}{|l|}{$f 2=48.1$} \\
\hline
\end{tabular}

\begin{tabular}{|c|c|c|c|c|c|c|c|c|}
\hline \multicolumn{5}{|c|}{ Lamivudine in Phosphate Buffer 6.8} & \multicolumn{4}{|c|}{ Zidovudine in Phosphate Buffer 6.8} \\
\hline \multicolumn{3}{|c|}{ Reference (Combivir) } & \multicolumn{2}{|c|}{ Test (Virex-LZ) } & \multicolumn{2}{|c|}{ Reference (Combivir) } & \multicolumn{2}{|c|}{ Test (Virex-LZ) } \\
\hline Time(min) & $\begin{array}{c}\text { Mean \% } \\
\text { Dissolved }\end{array}$ & STDEV & $\begin{array}{l}\text { Mean \% } \\
\text { Dissolved }\end{array}$ & STDEV & $\begin{array}{l}\text { Mean \% } \\
\text { Dissolved }\end{array}$ & STDEV & $\begin{array}{c}\text { Mean \% } \\
\text { Dissolved }\end{array}$ & STDEV \\
\hline 10 & 80.5 & 8.37 & 96.4 & 2.64 & 77.9 & 4.4 & 93.7 & 2.01 \\
\hline 20 & 84.9 & 9.04 & 102.5 & 5.05 & 80.6 & 4.1 & 100.3 & 1.57 \\
\hline 30 & 85.2 & 5.06 & 100.0 & 2.59 & 83.5 & 2.3 & 100.4 & 2.00 \\
\hline 40 & 89.7 & 6.02 & 99.1 & 7.21 & 85.6 & 2.5 & 101.5 & 1.95 \\
\hline 50 & 88.1 & 4.55 & 91.8 & 8.69 & 85.3 & 2.9 & 98.9 & 9.50 \\
\hline 60 & 87.2 & 6.13 & 87.0 & 7.76 & 85.3 & 4.1 & 87.8 & 4.68 \\
\hline \multicolumn{5}{|l|}{$f 2=39.6$} & \multicolumn{4}{|l|}{$\mathrm{f} 2=37.8$} \\
\hline
\end{tabular}

ensure that the bioavailability of the drug is not limited by dissolution. In which case, the rate-limiting step for drug absorption is gastric emptying, as in the case of BCS Class I APIs such as lamivudine and zidovudine (7). The mean T50\% gastric emptying time is 15-20 min under fasting conditions. According to the Guidance, a drug product undergoing $85 \%$ dissolution in 15 min under mild dissolution test condition of $0.1 \mathrm{~N} \mathrm{HCl}$ behaves like a solution and generally should not have any bioavailability problems (5).
Lazid released over $90 \%$ of lamivudine and zidovudine in the three media in $10 \mathrm{~min}$. Similarly, Virex-LZ released about $90 \%$ of lamivudine and zidovudine in $10 \mathrm{~min}$ in the three media. Lazid and Virex-LZ complied with the dissolution specification of not less than (NLT) $85 \%$ of the labeled content of the APIs in 30 min or less (5). By the above criteria, Lazid and Virex-LZ show rapid dissolution. The Combivir release of zidovudine in phosphate buffer $\mathrm{pH} 6.8$ was however less than $85 \%$ in 30 min. 


\begin{tabular}{|c|c|c|c|c|c|c|c|c|}
\hline \multicolumn{5}{|c|}{ Lamivudine in Phosphate Buffer 6.8} & \multicolumn{4}{|c|}{ Zidovudine in Phosphate Buffer 6.8} \\
\hline \multicolumn{3}{|c|}{ Reference (Combivir) } & \multicolumn{2}{|c|}{ Test (Lazid) } & \multicolumn{2}{|c|}{ Reference (Combivir) } & \multicolumn{2}{|c|}{ Test (Lazid) } \\
\hline Time(min) & $\begin{array}{c}\text { Mean \% } \\
\text { Dissolved }\end{array}$ & STDEV & $\begin{array}{c}\text { Mean \% } \\
\text { Dissolved }\end{array}$ & STDEV & $\begin{array}{c}\text { Mean \% } \\
\text { Dissolved }\end{array}$ & STDEV & $\begin{array}{c}\text { Mean \% } \\
\text { Dissolved }\end{array}$ & STDEV \\
\hline 10 & 80.5 & 8.37 & 94.2 & 1.79 & 77.9 & 4.36 & 88.0 & 8.42 \\
\hline 20 & 84.9 & 9.04 & 97.3 & 5.61 & 80.6 & 4.13 & 96.8 & 8.12 \\
\hline 30 & 85.2 & 5.06 & 91.2 & 1.89 & 83.5 & 2.28 & 92.0 & 1.74 \\
\hline 40 & 89.2 & 6.02 & 96.8 & 2.55 & 85.6 & 2.47 & 96.8 & 2.52 \\
\hline 50 & 88.1 & 4.55 & 99.2 & 2.07 & 85.3 & 2.92 & 100.4 & 1.87 \\
\hline 60 & 87.2 & 6.13 & 101.1 & 2.34 & 85.3 & 4.11 & 102.6 & 2.52 \\
\hline $\mathrm{f} 2=47.4$ & & & & & $\mathrm{f} 2=45.9$ & & & \\
\hline
\end{tabular}

\begin{tabular}{|c|c|c|c|c|c|c|c|c|}
\hline \multicolumn{5}{|c|}{ Lamivudine in $\mathrm{HCl}$ Medium } & \multicolumn{4}{|c|}{ Zidovudine in $\mathrm{HCl}$ medium } \\
\hline \multicolumn{3}{|c|}{ Reference (Combivir) } & \multicolumn{2}{|c|}{ Test (Virex-LZ) } & \multicolumn{2}{|c|}{ Reference (Combivir) } & \multicolumn{2}{|c|}{ Test (Virex-LZ) } \\
\hline Time(min) & $\begin{array}{c}\text { Mean \% } \\
\text { Dissolved }\end{array}$ & STDEV & $\begin{array}{c}\text { Mean \% } \\
\text { Dissolved }\end{array}$ & STDEV & $\begin{array}{c}\text { Mean \% } \\
\text { Dissolved }\end{array}$ & STDEV & $\begin{array}{c}\text { Mean \% } \\
\text { Dissolved }\end{array}$ & STDEV \\
\hline 10 & 85.2 & 5.35 & 97.6 & 16.86 & 81.1 & 3.43 & 94.5 & 16.56 \\
\hline 20 & 85.6 & 16.00 & 104.3 & 4.73 & 81.5 & 13.25 & 103.7 & 4.84 \\
\hline 30 & 95.4 & 5.93 & 105.4 & 7.75 & 89.4 & 3.68 & 105.7 & 8.35 \\
\hline 40 & 96.5 & 6.27 & 103.0 & 5.55 & 90.7 & 5.23 & 103.5 & 5.24 \\
\hline 50 & 98.7 & 6.48 & 101.5 & 6.30 & 92.7 & 3.75 & 109.9 & 22.92 \\
\hline 60 & 99.0 & 7.15 & 101.9 & 6.53 & 91.8 & 4.09 & 103.2 & 6.32 \\
\hline & & & & & $\mathrm{f} 2=37.6$ & & & \\
\hline
\end{tabular}

\begin{tabular}{|c|c|c|c|c|c|c|c|c|}
\hline \multicolumn{9}{|l|}{ Table 6} \\
\hline \multicolumn{5}{|c|}{ Lamivudine in $\mathrm{HCl}$ Medium } & \multicolumn{4}{|c|}{ Zidovudine in $\mathrm{HCl}$ medium } \\
\hline \multicolumn{3}{|c|}{ Reference (Combivir) } & \multicolumn{2}{|c|}{ Test (Lazid) } & \multicolumn{2}{|c|}{ Reference (Combivir) } & \multicolumn{2}{|c|}{ Test (Lazid) } \\
\hline Time(min) & $\begin{array}{c}\text { Mean \% } \\
\text { Dissolved }\end{array}$ & STDEV & $\begin{array}{c}\text { Mean \% } \\
\text { Dissolved }\end{array}$ & STDEV & $\begin{array}{c}\text { Mean \% } \\
\text { Dissolved }\end{array}$ & STDEV & $\begin{array}{c}\text { Mean \% } \\
\text { Dissolved }\end{array}$ & STDEV \\
\hline 10 & 85.2 & 5.35 & 108.0 & 2.82 & 81.1 & 3.43 & 106.9 & 3.41 \\
\hline 20 & 85.6 & 16.00 & 110.8 & 3.00 & 81.5 & 13.25 & 110.9 & 4.25 \\
\hline 30 & 95.4 & 5.93 & 108.2 & 3.76 & 89.4 & 3.68 & 108.2 & 3.54 \\
\hline 40 & 96.5 & 6.27 & 108.4 & 2.26 & 90.7 & 5.23 & 109.3 & 2.33 \\
\hline 50 & 98.7 & 6.48 & 106.0 & 4.13 & 92.7 & 3.75 & 105.9 & 3.88 \\
\hline 60 & 99.0 & 7.15 & 108.3 & 2.50 & 91.8 & 4.09 & 108.6 & 3.00 \\
\hline & & & & & $f 2=30.0$ & & & \\
\hline
\end{tabular}

A comparison of the dissolution profiles of the three antiviral drug combinations in the three different media was made (Figures 1-6). In some instances, the dissolution result indicated more than $100 \%$ release, which is a reflection of the overage of APIs in the product and is in agreement with the assay result of the products from the same batches.

The similarity of the dissolution profiles was determined using the similarity factor, $\mathrm{f}_{2}(5)$. Two dissolution profiles are considered to be similar when the $f_{2}$ value is greater than 50 and dissimilar when less than 50 (6). The $\mathrm{f}_{2}$ was not determined for the comparison of products with more than $85 \%$ release of API in 15 min because they were established to be very rapidly dissolving. The only circumstance in which $\mathrm{f}_{2}$ is not required according to the Guidance (6) is when $85 \%$ or more of the labeled amount of the drug dissolves in fifteen minutes. The $\mathrm{f}_{2}$ values were calculated only up to the first point at which $85 \%$ release was achieved and at the $30-$ min time point. Subsequently, $f_{2}$ was calculated to determine 


\begin{tabular}{|c|c|c|c|c|c|c|c|c|}
\hline \multicolumn{9}{|l|}{ Table 7} \\
\hline \multicolumn{5}{|c|}{ Lamivudine in $\mathrm{HCl}$ Medium } & \multicolumn{4}{|c|}{ Zidovudine in $\mathrm{HCl}$ medium } \\
\hline \multicolumn{3}{|c|}{ Reference (Lazid) } & \multicolumn{2}{|c|}{ Test (Virex-LZ) } & \multicolumn{2}{|c|}{ Reference (Lazid) } & \multicolumn{2}{|c|}{ Test (Virex-LZ) } \\
\hline Time(min) & $\begin{array}{c}\text { Mean \% } \\
\text { Dissolved }\end{array}$ & STDEV & $\begin{array}{c}\text { Mean \% } \\
\text { Dissolved }\end{array}$ & STDEV & $\begin{array}{c}\text { Mean \% } \\
\text { Dissolved }\end{array}$ & STDEV & $\begin{array}{c}\text { Mean \% } \\
\text { Dissolved }\end{array}$ & STDEV \\
\hline 10 & 108.1 & 2.82 & 97.6 & 16.86 & 106.9 & 3.41 & 94.5 & 16.56 \\
\hline 20 & 110.8 & 3.00 & 104.3 & 4.73 & 110.9 & 4.25 & 103.7 & 4.84 \\
\hline 30 & 108.2 & 3.75 & 105.4 & 7.75 & 108.2 & 3.54 & 105.7 & 8.35 \\
\hline 40 & 108.4 & 2.26 & 103.0 & 5.55 & 109.3 & 2.33 & 103.5 & 5.24 \\
\hline 50 & 106.0 & 4.13 & 101.5 & 6.30 & 105.9 & 3.88 & 109.9 & 22.92 \\
\hline 60 & 108.3 & 2.50 & 101.9 & 6.53 & 108.6 & 3.00 & 103.2 & 6.32 \\
\hline
\end{tabular}

similarity between Combivir and Virex-LZ and with Lazid in pH 4.5 phosphate buffer. The values 47.9 and 48 were obtained, respectively, for zidovudine release, indicating lack of similarity of these products at $\mathrm{pH} 4.5$. Calculations of $\mathrm{f}_{2}$ were done for Combivir versus Virex-LZ and Combivir versus Lazid for the release of lamivudine and zidovudine in $\mathrm{pH} 6.8$ phosphate buffer. The calculated $\mathrm{f}_{2}$ values in this study may have been compromised as only six data points per product were used instead of the recommended twelve.

Bioequivalence indicates that the rate and extent of absorption of two or more similar dosage forms containing similar amounts of the same drug do not differ significantly. The three products are chemically equivalent because they all contain lamivudine and zidovudine at the same label strength as stated above. However, Lazid and Virex-LZ differ from Combivir in their dissolution characteristics. Virex-LZ and Lazid showed greater than $85 \%$ dissolution of both APIs in 15 min or less in $0.1 \mathrm{~N} \mathrm{HCl}(\mathrm{pH} 1.2)$ and in $\mathrm{pH} 4.5$ and 6.8 phosphate buffers and can be classified as very rapidly dissolving products. Therefore, these two products can be considered to have similar dissolution characteristics, and since both of the actives are BCS Class I APIs, it can also be assumed that they are bioequivalent to each other. By contrast, Combivir did not meet all the criteria for a rapidly-dissolving product. Furthermore, $f_{2}$ analysis showed that dissolution of the APIs from Combivir is dissimilar to that from Lazid and Virex-LZ. It can be concluded that Lazid and Virex-LZ may be used interchangeably.

\section{References}

1. Thomas, A. G. AIDS: A Primer for Pharmacists on Therapeutic Control and Patient Counseling. The CE
Solution; Florida Continuing Pharmaceutical Education: Riverview, FL, 2003.

2. Federal Ministry of Health, National Action Committee on AIDS. Situation Analysis Report on STD/HIV/AIDS in Nigeria; Journalists Against AIDS Nigeria: Lagos, Nigeria, 2000.

3. World Health Organization, Department of HIV/AIDS. Summary Country Profile for HIV/AIDS Treatment Scaleup: Nigeria; Geneva, Switzerland, 2004.

4. Abuga, K. O.; Mwagiru, P. M.; Thoithi, G. N.; Nguyo, J. M.; Ngugi, J. K.; King'Ondu, O. K.; Mugo, H. N.; Kibwage, I. O. Quality of Antiretroviral Drugs Analyzed in the Drug Analysis and Research Unit During 2000-2003. East Central African J. Pharm. Sci. 2003, 6, 20-23.

5. Dissolution Testing of Immediate Release Solid Oral Dosage Forms; Guidance for Industry; U.S. Department of Health and Human Services, Food and Drug Administration, Center for Drug Evaluation and Research (CDER), U.S. Government Printing Office: Washington, DC, 1997.

6. Waiver of In Vivo Bioavailability and Bioequivalence Studies for Immediate-Release Solid Oral Dosage Forms Based on a Biopharmaceutics Classification System; Guidance for Industry; U.S. Department of Health and Human Services, Food and Drug Administration, Center for Drug Evaluation and Research (CDER), U.S. Government Printing Office:Washington, DC, 2000.

7. World Health Organization. WHO Expert Committee on Specifications for Pharmaceutical Preparations; WHO Technical Report Series No. 937; Geneva, Switzerland, 2006. 